\title{
Reframing Wildfire Simulations for Understanding Complex Human-Landscape Interactions in Cross-Cultural Contexts: A Case Study from Northern Australia
}

\author{
Rohan Fisher ${ }^{1,2, *}$, Scott Heckbert ${ }^{3,4}$ and Stephen Garnett ${ }^{1}$ \\ 1 Research Institute for Environment and Livelihoods, Charles Darwin University, Darwin, NT 0909, Australia; \\ stephen.garnett@cdu.edu.au \\ 2 Northern Institute, Charles Darwin University, Darwin, NT 0909, Australia \\ 3 Department of Geography, University of Lethbridge, 4401 University Drive, Lethbridge, AB T1H 3M4, \\ Canada; Scott.Heckbert@aer.ca \\ 4 Alberta Energy Regulator, 4999-98 Avenue, Edmonton, AB T6B 2X3, Canada \\ * Correspondence: rohan.fisher@cdu.edu.au
}

Citation: Fisher, R.; Heckbert, S.; Garnett, S. Reframing Wildfire Simulations for Understanding Complex Human-Landscape Interactions in Cross-Cultural Contexts: A Case Study from Northern Australia. Fire 2021, 4, 46 https://doi.org/10.3390/ fire 4030046

Academic Editors: Fantina Tedim,

Vittorio Leone and

Carmen Vázquez-Varela

Received: 18 June 2021

Accepted: 10 August 2021

Published: 13 August 2021

Publisher's Note: MDPI stays neutral with regard to jurisdictional claims in published maps and institutional affiliations.

Copyright: (c) 2021 by the authors. Licensee MDPI, Basel, Switzerland. This article is an open access article distributed under the terms and conditions of the Creative Commons Attribution (CC BY) license (https:// creativecommons.org/licenses/by/ $4.0 /)$.

\begin{abstract}
An increase in the frequency of severe fire events, as well as a growing interest in wildfire mitigation strategies, has created a demand for skilled managers of landscape fire and a better community understanding of fire behaviour. While on-ground experience is essential, there is potential to substantially enhance training and community engagement with explanatory simulations. Through this work, we explore landscape fire behaviour as a complex system where understanding key behaviour characteristics is often more important and achievable than prediction. It is argued that this approach has particular value in Northern Australia, where fires burn across vast and sparsely inhabited landscapes that are largely under Indigenous ownership. Land and fire management in such complex cross-cultural contexts requires combining traditional and local knowledge with science and technology to achieve the best outcomes. We describe the workings of the model, a stochastic cellular automata fire behaviour simulation, developed through a participatory modelling approach for Northern Australia; the outputs generated; and a range of operational applications. We found that simulation assisted training and engagement through the development of an understanding of fire dynamics through visualisation, underpinned by landscape data sets, and engaging a culturally diverse set of land managers in discussions of fire management. We conclude that there is scope for a broader use of explanatory fire simulations to support development of shared understandings of fire management objectives.
\end{abstract}

Keywords: fire spread simulation; savanna landscapes; modelling; Indigenous knowledge

\section{Introduction \\ 1.1. Background}

As climate changes, the frequency, severity, and extent of fires are increasing in many parts of the world [1], with record-breaking fires occurring in both the northern and southern hemispheres in the last five years [2]. This has led to significant attention being paid to the role of traditional Indigenous burning practices that have managed fire risk for a millennium [3-5]. There is a growing realisation that adaptation to this increase in extreme fire weather requires skilled managers of landscape fire, as well as a better understanding of diverse wildfire risk mitigation strategies [6]. In support of this there is potential to augment planning and stakeholder engagement with explanatory fire simulations aimed at developing a more sophisticated understanding of the complexity of fire behaviour and fire management through the incorporation of local and traditional ecological knowledge.

However, fire behaviour modelling has traditionally focused on providing predictive, rather than explanatory, tools using empirically derived rate of spread algorithms. In this 
paper, we explore how taking a more heuristic and descriptive approach to understanding the complexity of fire behaviour can improve the learning, cross-cultural communication and planning utility of fire simulations in a way that models designed primarily for prediction may not afford.

The fire simulation approach described in this paper has been developed in the context of northern Australian savannas where wildfires burn vast landscapes and fire management is focused on cultural considerations, biodiversity and carbon abatement rather than emergency management [7]. In these landscapes, local knowledge is commonly extensive and sophisticated whilst data sets for fire spread prediction are limited and imprecise. In addition, local capacity for developing and implementing large scale prescribed burning is often low. In such circumstances, clear communication around fire management objectives and why particular burning strategies are being undertaken are important aspects of wildfire mitigation planning and critical for ensuring culturally appropriate practice on Indigenous lands $[8,9]$.

This study aims to address the need for tools that assist clear communication around fire management. These aims guided the development of an interactive and visually dynamic simulation platform that illustrates the complexity of fire behaviour and incorporates local knowledge in both the model structure and through facilitating self-directed exploration of fire management scenarios. Fire behaviour is complex and fire management requires a sophisticated understanding of the key drivers and the way they interact over multiple spatial and temporal scales. Complex system simulations focus the intent of model development on describing the key variables, their interactions and emergent outcomes [10]. These complex system models have been described as "tools to think with", helping users understand the dynamics and boundaries of real systems through testing, experimentation and play [11]. This "thinking through play" approach to modelling underpinned a focus on illustrating key fire behaviour and management principles in a way that is easy to explain to others and for the model interface to be simple enough for people with limited technical skills to use. Importantly these models are not predictive. Rather they are tailored as education tools [12], they describe enough of the complex interactions between the drivers of fire behaviour to be realistic, but are not designed for precise simulation of fire progression or absolute quantification of burn probability.

Over the last thirty years there has been considerable work done to incorporate Indigenous peoples' knowledge, skills and interests in natural resource management driven by an increasing acknowledgement of legal rights to land and self-determination and existing sophisticated land management skills [13-15]. Similarly, the importance of combining Indigenous and non-Indigenous knowledge for natural resource management to produce sustainable and equitable outcomes has become increasingly accepted [15-17]. Currently, most fire management is framed using non-Indigenous tools and management methods. The aim of developing the simple fire behavior simulation tool described here is to help bridge discussions between different cultural perspectives of fire management. Although traditional fire spread simulation models are commonly used to engage broader stakeholder groups in fire management discussions, there has been little work done looking specifically at developing tools focused on engagement and discussion in complex crosscultural contexts.

The following sections describe fire as a complex system and how simulations and participatory modelling were used to illustrate the complexity of fire management. Based on this we summarise the key components of a cellular automata simulation model for illustrating fire management principles and describe several operational examples using the fire simulation in a range of social and cultural settings across the savanna landscapes of Northern Australia.

\subsection{Fire as a Complex System}

Landscape and ecosystem processes, like all complex systems, evolve through interconnections and adaptive feedback loops between multiple spatial-temporal scales leading 
to emergent higher-order patterns and non-linear outcomes, which cannot be predicted by assessing the sum of their constituent parts [10]. They are also sensitive to initial states and minor perturbations, whereby a single factor can result in a fundamental change to the whole system [10,18-20].

By operating over multiple spatial-temporal scales, fire spread exhibits all of these complex system characteristics [21]. Fire weather conditions change over seconds in the case of wind gusts, prevailing wind patterns, temperature, and humidity vary over hours through diurnal cycles; temperature, humidity, and fuel curing are seasonal, and longerterm climatic cycles or climate change generate conditions that differ from one year to the next [22-24]. Landscape characteristics that influence fire spread also vary over multiple scales and interact with fire weather. For example, wind speed and direction have regional characteristics but will also be significantly altered by micro-scale topographic effects. Likewise, fuel curing levels are linked to both a seasonal cycle and small-scale variations in topographic hydrology. Fuel accumulation also operates over long time scales and is impacted by previous fires. To add to the complexity, minor perturbations, such as a wind gust that lofts a burning ember across a fire break, can unexpectedly change the character of a whole fire system [25-28]. Such chaotic, unpredictable, but common perturbations in fire behaviour have effects that are important to understand but difficult to model.

\subsection{Simulation and Participatory Modelling for Managing Complex Systems}

Scenario gaming has long been used by emergency responders to build creative and flexible thinking. Building on this tradition of scenario role-playing, computer simulation "games" are being increasingly applied to natural hazard planning, particularly in flood mitigation and response [29-31]. As with flood risk, we argue there is a role for understanding fire management as a complex social-ecological system where simulation games can play a role in developing a shared understanding of key variables, interactions and possible outcomes [31].

Simulation games are often used to support participatory modelling activities designed to engage stakeholders and allow local knowledge to be incorporated into planning processes [32-37]. Participatory modelling commonly involves a multi-phase engagement, extending from development to implementation, [38,39] and is important in ensuring the model illustrates key patterns and management concepts to support meaningful learning and discussion. Participatory modelling can also be used to support learning between different knowledge systems, such as between scientific and Indigenous knowledges [40]. In this context, it can provide a platform for "two-way learning" that supports the development of a shared understanding amongst multiple stakeholders $[39,41]$.

The work described in this paper was underpinned by five key principles guiding participatory modelling as outlined by Voinov [39]:

1. Facilitate and encourage learning from each other and the process;

2. Keep it flexible and focus on the process rather than the product;

3. Promote adaptive management, adaptive modelling and adaptive decision making

4. Accept a different kind of uncertainty - be certain about uncertainty; and

5. Accept untraditional metrics of success, validation and verification.

Reflecting these principles, this study emphasises the role of spatially explicit simulation to support both understanding of a dynamic complex system and cross-cultural communication through visualisation and interaction.

\subsection{Study Landscape and Current Fire Management Practice}

The savannas of Northern Australia have a monsoonal climate with a short, intense wet season and a long dry season. This climate promotes rapid grass growth followed by a long period of curing that creates one of the most fire-prone landscapes in the world [42]. Australia's tropical savannas cover 1.9 million $\mathrm{km}^{2}$ (around a quarter of the continental landmass), with an average of nearly $20 \%$ burning each year [43]. Fire management that reduces the prevalence of relatively severe late dry season wildfires $[7,44,45]$ has the 
potential for significant positive biodiversity [46-51] and greenhouse gas (GHG) abatement benefits [52,53]. This has resulted in savanna fire management being incorporated into an emission reduction methodology being implemented by the Australian Government [7]. The availability of carbon abatement funds for prescribed burning practices that reduce the frequency of late Dry Season fires has resulted in a rapid increase in active fire management, much of it on Indigenous lands, employing Indigenous land managers.

A common approach to this fire management in Northern Australia has been to conduct prescribed burns in the early Dry Season using ground-based burning and aerial incendiaries dropped from a helicopter [44,54]. These early Dry Season fires generally burn with relatively low intensity and, by reducing grass fuel loads, reduce the probability that more severe late Dry Season fires will spread $[55,56]$. The potential biodiversity, GHG emission, economic and regional employment benefits from improved fire management are substantial but they will only be realise by increasing the capacity of local land managers to implement effective burning strategies [43].

Land managers currently use a broad range of tools to support fire management planning, implementation, evaluation and communication throughout the year. At the beginning of each year, areas in need of protection from fire are identified, such as key infrastructure, sacred sites or environmentally sensitive areas. Managers use both spatial data and local knowledge to assess where fires might come from and whether landscape features might propagate or impede fires [57,58]. This local knowledge is supported by satellite-derived fire mapping provided through the North Australian Fire Information (NAFI) service [59]. These maps of burnt areas help users estimate fuel loads in order to evaluate the potential spread of an incendiary drop [58]. This information is also used to develop vegetation age mosaic datasets that inform biodiversity considerations in fire management.

However, many Indigenous people across Northern Australia, (due to poor technological literacy, remoteness and a lack of English fluency) cannot easily access and effectively use such spatial data. In addition, satellite-derived data is only one component of fire planning; effective burning needs to consider the factors that influence local fire spread, which is a complex interaction between fuel loads, fuel types, curing, wind speed, wind direction, temperature, and humidity. Due to the complexity of fire behaviour, there is often a fine line between where and when burning will produce a "good" outcome, no fuel reduction, or a catastrophic outcome. The ability to explore this boundary safely is vital to thinking through and communicating burning strategies. However, developing burning plans and communicating objectives and outcomes is challenging, particularly in the diverse cultural-linguistic environment of Northern Australia [8,9].

The aims of fire management, the cultural context, and the management resources outlined above are very different to those in Southern Australian, European or North American contexts. Instead of rate of spread estimates to support emergency response, the greatest need in the savannas of Northern Australia is for a more sophisticated understanding of the key factors involved in the propagation and extinguishment of fire to support land management objectives. To facilitate this, there is a need for descriptive models for these savanna landscapes that:

- $\quad$ help people use fire-related data sets to understand fire dynamics

- allow users to visualise how fire behaviour is affected by interactions between landscape and fire weather variables

- facilitate the communication of fire management goals and strategies between a culturally diverse set of land managers

The novelty of this work, therefore, relates to the application of complex systems and participatory modelling approaches to support these three objectives rather than the development of new spread algorithms. The first step in this process was the creation of a model interface that was easy to explain and that readily supports engagement with a broad range of potential users. The simulation we created aimed both to cover the key system components and to balance the complexity of their interactions with a level of simplicity 
that allowed user-led enquiry with little explanation. The model was particularly designed to illustrate prescribed burning processes, emphasising factors that propagate or retard fire in Northern Australia rather than the "rate of spread".

\section{Methods}

\subsection{Fire Propagation Modelling for Northern Australia}

The key concepts that models of savanna fire must capture were derived by the lead author from over a decade of providing Northern Australian fire managers with landscape data to support wildfire mitigation operations. These include:

- Variation in fuel loads and their state of curing: models should include estimates of the amount of grass fuel and its capacity to carry fire, which vary with location in the landscape, time since the last rain, and time since the previous fire at a location.

- Pre-existing fire breaks: watercourses and cliff lines can prevent the spread of fires, as will anthropogenic features such as roads and fence lines. Models should show how strengthening existing impediments to fire spread by lighting fires alongside them in the early Dry Season can increase their effectiveness at stopping fires under more extreme fire weather conditions.

- Terrain and fire weather: fires more readily propagate uphill than downhill, downwind than upwind, and on hot dry days rather than cool or humid days. Models must therefore include slope and variables that account for humidity and temperature variation, as well as wind speed and direction, both seasonally and during the diurnal cycle. Both wind speed and temperature tend to increase in intensity in the afternoon, while at night the wind dies and the temperature often drops below the dew point, meaning that moisture forms on fine fuels.

- Unpredictable fire behaviours: models must incorporate the uncertainty arising from significant changes in burn patterns caused by minor variations in landscape features or fire weather conditions.

\subsection{Simulation Model Structure and Data}

The model parameters and attributes are summarised in the following section with a more detailed description provided in the supplementary model description. Where possible the model is parametrised using empirical data. Because such data are scarce, however, most parameters have been developed iteratively over a decade of working with fire managers to ensure that the representation of fire behaviour performed accurately and reliably relative to the mental models of industry experts and stakeholders. While more detail of the model code is available at the GitHub repository hosting code for a sample model of the simulation (https://github.com/rohanfisher/incendiarysim), we emphasise that this is a simulation model not a predictive model.

The model was developed using NetLogo [60] which was designed to support transparent, sharable and adaptable simulations of complex systems and is the most commonly used modelling platform for agent-based modelling. The model represents fire spread over a multi-layer raster grid of landscape variables, similar to other cellular automata models of fire spread [61-63]. However, within NetLogo, the probability of a cell igniting is calculated by active "fire agents" interacting with the landscape and global variables to define the spread probability from a "burning cell".

In summary, fire spread is determined through interaction between three model variable types:

1. global fire weather variables,

2. raster spatial layers representing landscape characteristics, and

3. "burning cell" attributes.

A random value of spread potential is also calculated for each cycle of the model with fire moving to an adjacent cell if the spread potential value is below the ignition probability value. 


\subsubsection{Fire Weather Characteristics}

The key fire weather parameters of temperature, humidity and fuel curing in Northern Australia are strongly tied to seasonal influences. Grasses progressively cure, temperatures increase, and humidity decreases as post-monsoon early Dry Season conditions set in usually around April. This continues until the first wet-season rain late in the year. Four global variables drive fire weather; fire danger, wind speed, wind direction and time of day.

Fire danger in the model combines curing, temperature and humidity. The onset of the Dry and Wet Seasons can vary significantly both spatially and annually [64]. Rather than set a seasonal value for fire danger, a scale from one to ten indicates a range from wet and cool conditions to hot, late Dry Season fires.

Wind speed affects the rate and direction of spread, as well as the likelihood of spotting, when aerial embers fly ahead of a fire front starting new fires. While very hard to predict, spotting is important to consider in fire management. Wind speed has four settings in the simulation: none, low, medium, and high. High wind speed allows spotting to occur, igniting cells at a random distance in the prevailing wind direction ahead of the initiating cell. Work in forested landscapes of Southern Australia have mapped spotting events over five kilometres from a fire front [65] but such distances are less likely in Northern Australia where wind speeds during the fire season are generally low. Whilst there have been no empirical studies, northern fire managers noted, during refinement of the model, that spotting often occurs up to $500 \mathrm{~m}$ in advance of many fire fronts. Spotting distance for the purposes of this model was therefore calculated as a random value between $20-500 \mathrm{~m}$ with rapidly decreasing probability of spotting greater than $150 \mathrm{~m}$. In the model, regular spotting is set to occur only at strong wind speeds. However, spotting at a medium wind speed setting is possible due to randomly generated strong wind gusts. Fluctuations in wind speed are modelled using a Markov chain function that allows wind speed to change temporarily around an initial setting.

Temperature, humidity, and wind speed vary with time of day. Fire danger is lowest at dawn when humidity is highest, the temperature is the lowest, and there is a chance for dew to form on fine fuels. Morning dew, which is related to changes in humidity and temperature, is an important factor in early morning fire extinguishment. During the mid-afternoon when the temperature is highest and the humidity is lowest, there is the greatest fire danger. However, temperature and wind speed generally drop in the evening, while humidity increases, lessening fire danger. These variations have been modelled in the simulation, such that the time of day affects the fire danger and wind speed settings, with the latter modelled as being higher in the daytime, and declining after sunset as the land cools and reaches an equilibrium with the surface-atmosphere [66].

\subsubsection{Landscape Characteristics}

The amount of fuel available is derived from grass fuel accumulation curves developed by Yates et al. [67]. These fuel accumulation functions are based on grass type and time since last burn, both available from NAFI, based on MODIS 250m satellite data. Grass types were characterised as "hummock" (Triodia spp.), "tussock" (a wide variety of annual and perennial grasses) and a mix of the two as these capture much of the variation on grass flammability and fuel accumulation rates.

Slope influence on fire spread is calculated as the relative difference in elevation between a burning cell and each of its eight neighbours, with the elevation of a cell obtained from the Shuttle Radar Topographic Mission data (SRTM) [68]. Slope also controls drainage, which is used as a proxy for differential curing after the Wet Season and grass growth rates. This "local curing" was produced using the SAGA GIS [68] wetness index, which models water flow and accumulation. Anthropogenic firebreaks, including major roads, fence lines, and urban areas, are extracted as vector data from Northern Territory Government infrastructure mapping and augmented using Google Earth imagery both to update the data with new features and to add a break-width factor or the stopping power 
attribute to each feature. Regarding natural firebreaks, waterway locations are derived from national level waterway vector data [69] and cliff lines from national topographic mapping.

\subsubsection{Burning Cell Spread Probability}

On each cycle of the model (Figure 1), landscape and fire weather variables interact to produce an ignition probability. "Ignition probability" - the probability of a fire moving to an adjacent cell-is the product of the "spread probability" of a burning cell and the "burn probability" of adjacent cells. The interaction between these variables is shown in Figure 1 and summarised here:

Variable 1. BurnProbability $=$ Fuelload $\times$ FireDanger $\times$ LocalCuring

Variable 2: SpreadProbability $=$ Wind $\times$ Slope $\times$ TimeSinceIgnition

Variable 3: IgnitionProbability $=$ SpreadProbability $\times$ BurnProbability

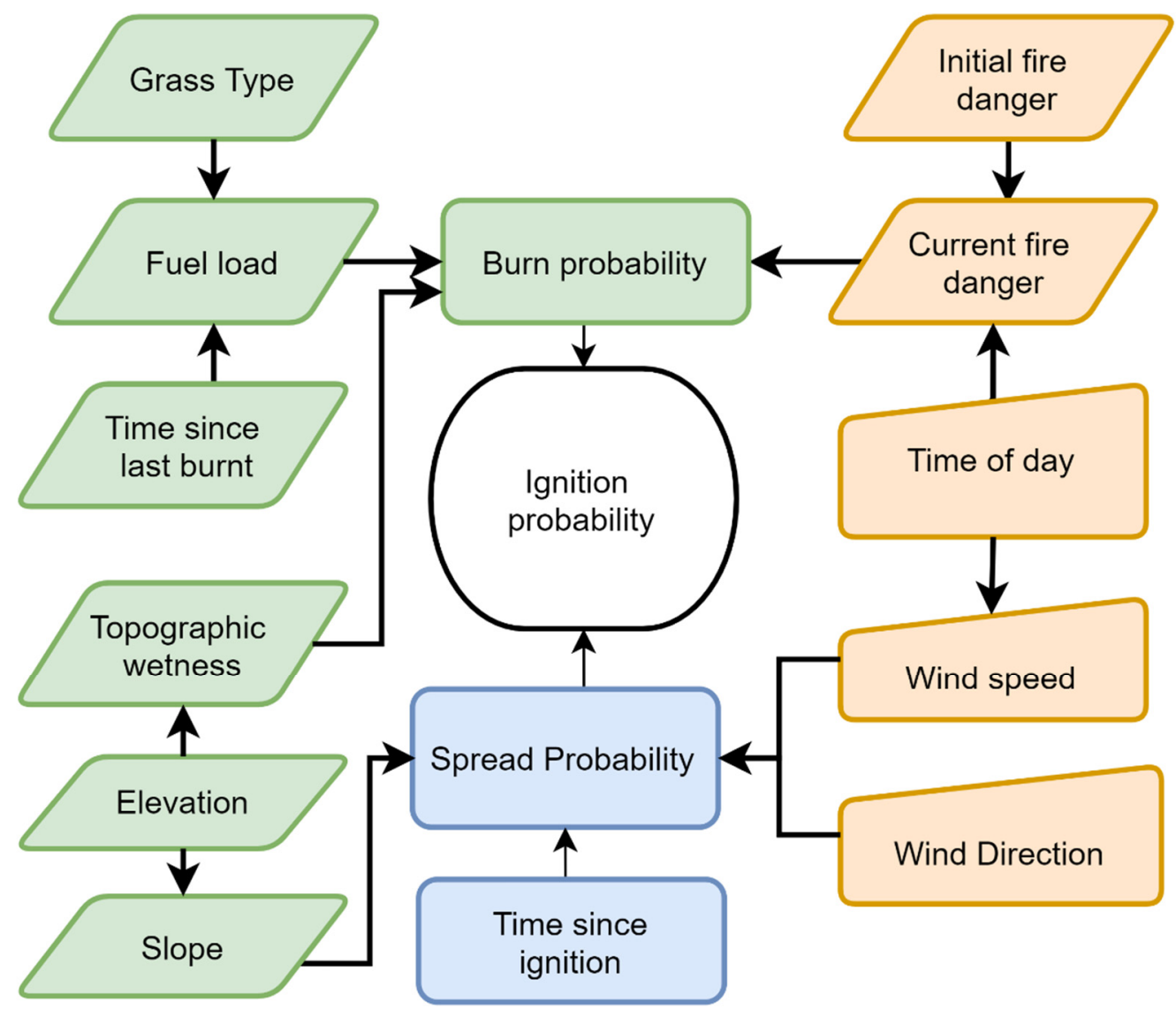

Figure 1. Factors that determine the ignition probability of a cell, based on landscape factors (green), global fire weather factors (orange) and a burning cell condition (blue).

Burn probability is calculated for each cycle of the model and is a function of fuel load, current fire danger and local curing.

The influence of fire danger (humidity, temperature, and curing) increases rapidly after the Wet Season ends, levelling out later in the year. The influence on "Burn Probability" is modelled to reflect this. The current fire danger is a function of the initial fire danger setting modified by the time of day. Fire danger moves around the initial setting through the diurnal cycle, being highest during mid-afternoon (modelled as an increase in the fire danger by one level) and decreasing during the evening to its lowest level at dawn (modelled as three fire danger values lower than the initial setting). Local curing is derived from the topographic wetness layer and modified by the initial fire danger. 
Spread probability is a function of wind direction and strength, slope and the time since a cell ignited. This is calculated by "burning" cells for each surrounding cell every cycle of the model. The slope influence is calculated using the function developed by Nobel et al. [70].

As the simulation functions as a "stochastic cellular automata", the rate of spread is not explicitly coded into the model. However, fire front movement has been calibrated through multiple model runs to approximate the rate of spread functions for tropical savannas described by Cheney [71] and for hummock grasses described by Griffin and Alan [72].

\subsection{Model Refinement through Participatory Engagement}

Development of the simulation involved discussions and feedback from a wide variety of land managers to incorporate their experience of savanna fire behaviour. This participatory modelling process was used to fine-tune the system dynamics of the simulation to ensure that key aspects of savanna fire behaviour were incorporated. At one workshop, it was noted that grass fuel along drainage lines cured more slowly and so retarded fire spread, the total fuel load was generally higher than in drier parts of the landscape and, therefore, once cured, could act as a "wick", facilitating spread. This alternative view on the way drainage lines can influence fire behaviour was incorporated into the model by modifying the influence of the topographic wetness layer relative to the fire danger setting because drainage lines are often used as natural fire breaks, which can be enhanced by early Dry Season burning. The observations also helped explain how buffering drainage lines by burning early in the year can help prevent the spread of fires later in the year. Conversely, burning near drainage areas too late in the year can result in a serious unintended expansion of the extent and severity of fires.

Another observation was that in landscapes grazed heavily by domestic stock or feral ungulates some areas did not burn because they lacked sufficient fuel. Identifying regions where grazing pressure was having a significant influence on fuel load required reference to local knowledge. In areas where grazing was identified as influencing fire frequency, fuel load within the model was modified accordingly.

Two further refinements to the model, derived from user feedback, were related to the visual interpretation of fire weather effects. The first involved the inclusion of smoke, which provided immediate visual cues as to the size of a fire (the number of burning cells) as well as wind direction and speed. Smoke also gave a more "realistic" feel to the simulations in progress. The other visual refinement was to darken and lighten the model through the day-night cycle, as well as adding labels indicating the approximate time of day. This made it easier for users to understand how fire behaviour varies with changing weather conditions.

\section{Results}

\subsection{Simulation Model Interface and Outputs}

The model interface (Figure 2) is composed of six main sections: fire weather variables, landscape maps, play interface, additional settings, and reporting information. The fire weather variables enable modifications of ignition settings which include fire danger, wind speed and direction, and time of day. The maps show landscape variables that affect fire spread as well as locations of significant sites, for instance, camping areas or places of cultural value. It is also possible to display the previous year's burning by month.

The play interface is where the user initiates fire. The "ignite" button allows the user to "draw" ignition points across the landscape. It is possible to save these ignition points and reignite them under varying weather conditions. The "go" button within the "play" interface begins a model run showing a dynamic animation of fire spread within the map window based on chosen settings. Fire weather variables can be altered during the course of a model run, allowing users to explore changing fire behaviour as it appears to be occurring (video examples of dynamic simulation runs can be accessed 
via https:/ /incendiarysim.wordpress.com/video-fire-as-a-complex-system/). Additional settings allow the user to draw fire breaks, simulate a random lightning strike and add specific "high-value" points that need protection, such as key infrastructures or sacred sites.
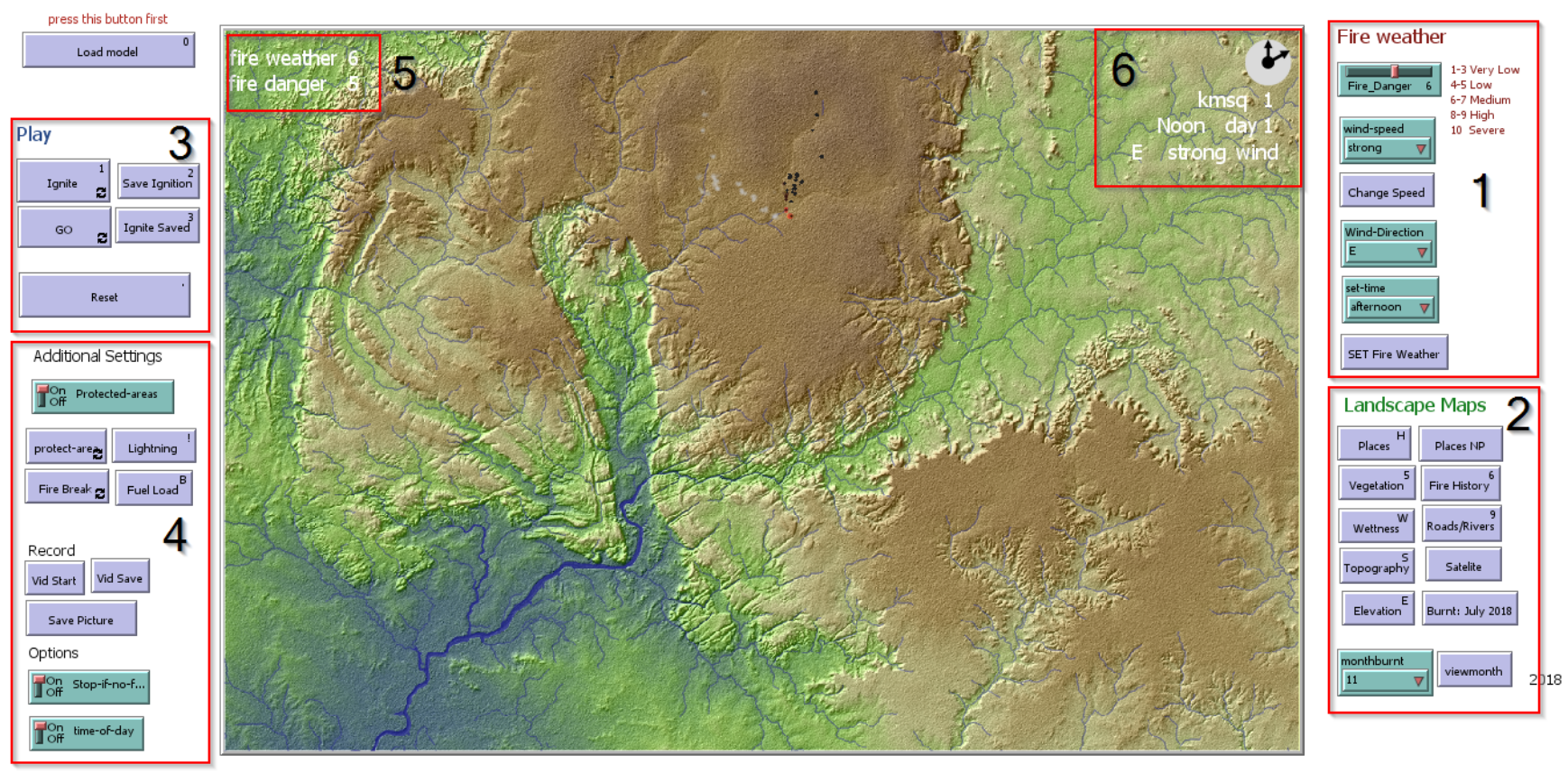

Figure 2. The NetLogo interface showing (1) fire weather, (2) landscape variables, (3) the ignition interface, (4) additional settings to simulate lightning strike or add points of high-value areas needing protection, (5) fire danger monitor, and (6) the area burnt, winds speed, and time monitoring.

The simulation outputs aim to represent fire behaviour and the strategies used to manage it by reproducing spread patterns and dynamics resembling real-world experience. For example, one common fire management practice is to conduct prescribed burning that controls fire spread (Figure 3). Similarly, whilst not informing "active" fire management decisions, the model has been used to incorporate satellite-derived burnt area mapping for an active fire season to help illustrate where there may be gaps in prescribed burning work. The idea is to illustrate principles around prescribed burning in a visually dynamic way to help communicate about fire spread risks.

Built into the simulation interface is the ability to save ignition points and explore fire behaviour under multiple fire weather settings. In Figure 4, this is illustrated as a matrix or potential fire spread outcomes using the combination of three fire danger and wind speed settings and a diagonal aerial incendiary ignition line. The low fire danger shows limited spread with fires extinguishing during the evening of the first. This suggests that under these fire weather conditions, although there is little risk of a fire "escaping", the amount of fuel reduction to form a contagious break may be insufficient. The high fire danger outcome shows substantial and ongoing spread in all cases. With no wind, the fire moved in an easterly direction, following high fuel loads related to the spinifex habitat, which had not been burnt for many years. With a medium windspeed, the fire was able to follow high fuel loads to the north-west, as well as the east. This suggests that high fuel load spinifex landscapes should be burnt earlier than lower fuel load escarpment landscapes. Only with a strong wind setting does fire in low fuel load escarpment regions continue to burn whilst solid and continuous fuel reduction breaks are achieved at lower wind speeds. Under a very high fire danger setting, the spread continues under all fuel load conditions, albeit to a much greater extent when combined with a strong wind. 


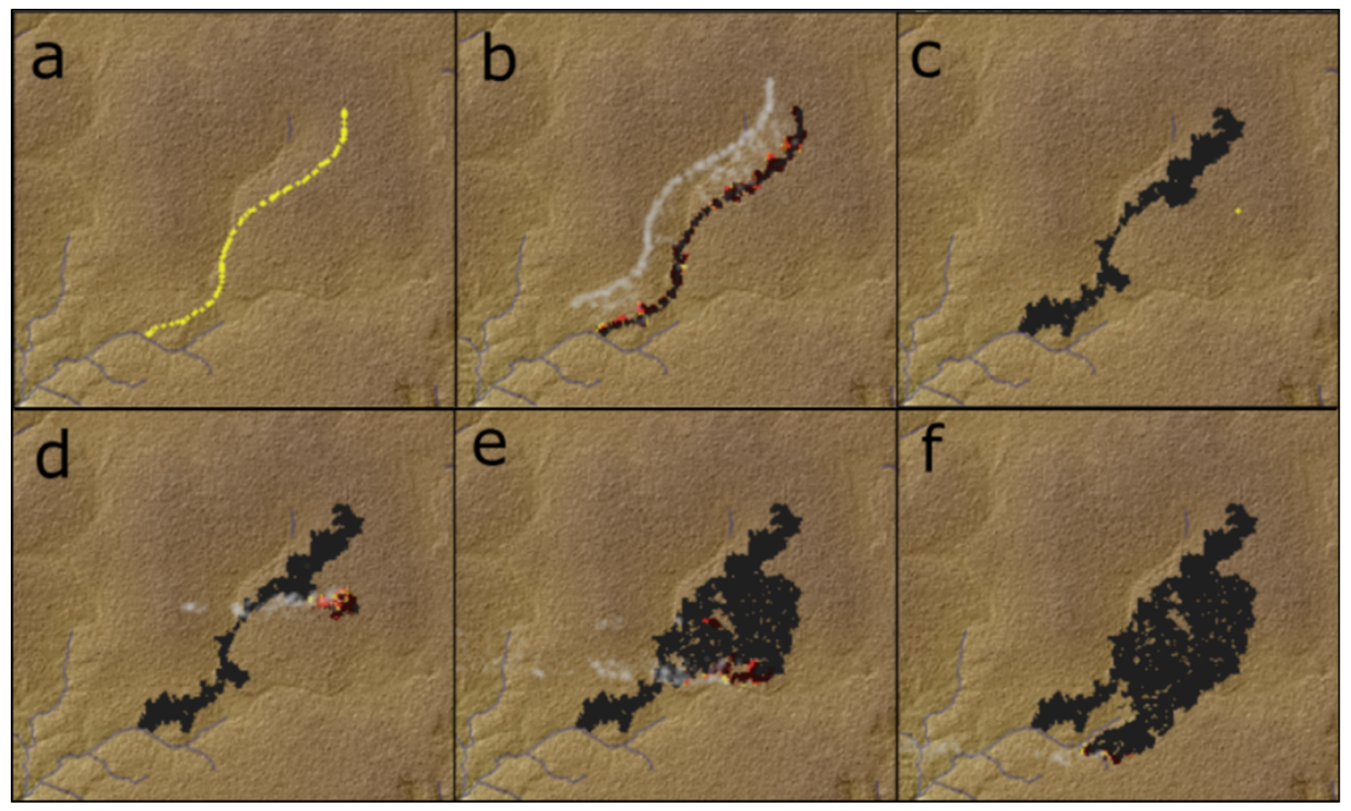

Figure 3. Simulated application of aerial incendiaries to create fire breaks. The sequence (a-c) shows what the successful application of incendiaries to create a burnt area might look like with a few gaps that self-extinguished in the evening. In box (b) white "smoke" can be seen from the initial ignition Box (a) and emanating cells that are still burning. Box (c) also shows a simulated ignition point east of the break, with the sequence (d) showing fire spread from this point later in the Dry Season with a strong easterly wind. The simulated fire is largely contained from the further westerly spread by Day 2 , as shown in box (e), but continues to burn slowly around the break before continuing its easterly trajectory, as shown in box (f). Were this real, a pattern like this would suggest the need for on-ground intervention to contain the fire front.

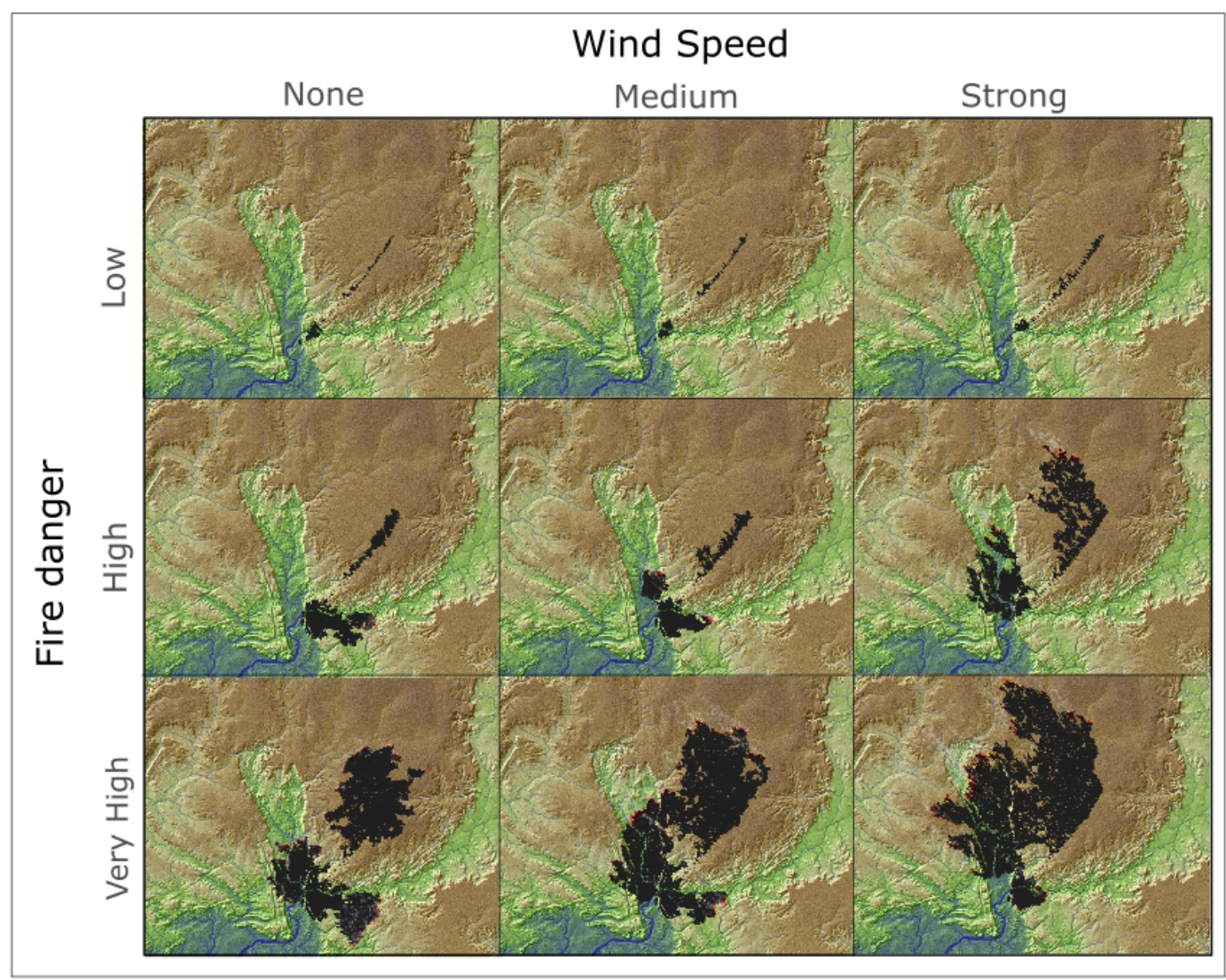

Figure 4. Simulated fire spread matrix based on a combination of three fire danger settings (Low, High, Very High) and three windspeed settings (None, Medium, Strong). 
This technique can also help visualise inherent, unpredictable variability in fire behaviour by running the same model multiple times with the same settings. A set of repeated simulations is shown in Figure 5a. In four cases (1, 2, 4, and 7), fires jumped the road breaks due to random wind fluctuations, while spotting events in four cases $(3,5,8$, and 9$)$, but were contained by a nearby river. In one case (6), the fire jumped both the road and river barriers and continued burning over a much larger area.

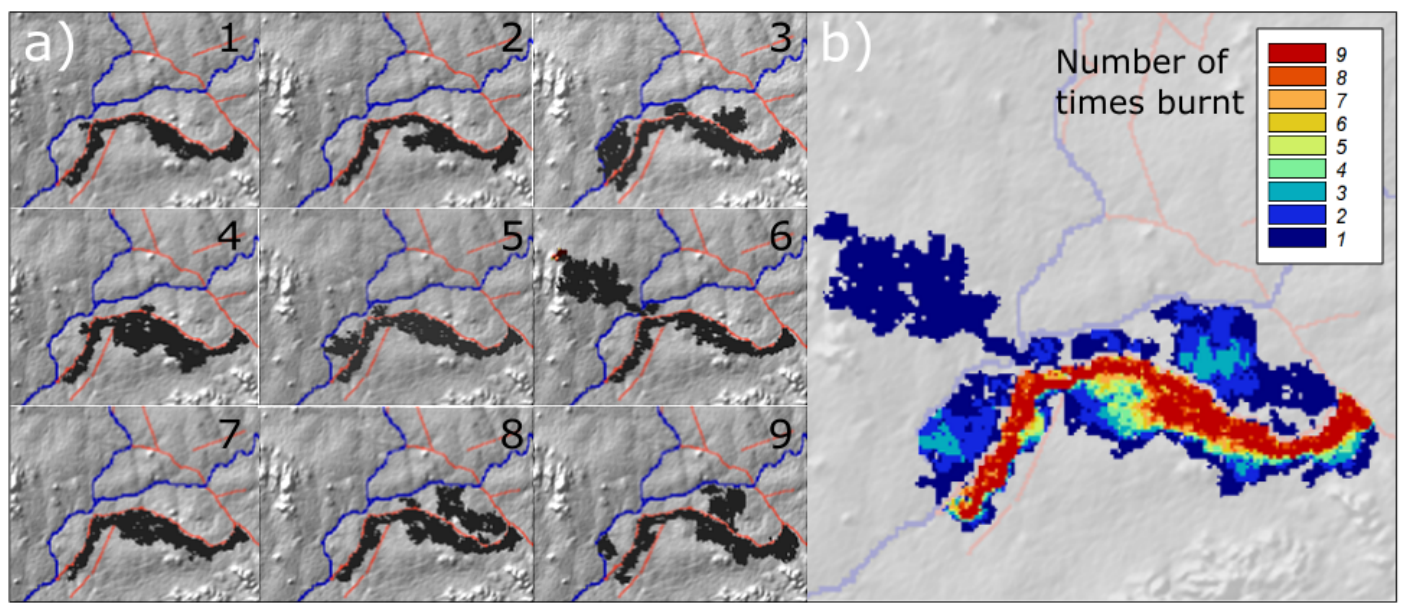

Figure 5. Nine model runs with the same fire weather conditions showing each model run (a) and the number of times "burnt" (b).

The sum of these runs using the behaviour space function (Figure 5b) further helps visualise fire behaviour and demonstrate variability in risk because some areas will be burnt repeatedly, but others will burn very rarely (Figure 5b). Thinking of fire behaviour in terms of probabilistic outcomes helps managers understand the risks and develop plans that factor in uncertainty.

\subsection{Applications}

The simulation model is designed for use in fire management workshops and community engagement activities with Indigenous ranger groups and government fire management agencies. Three case studies, all in the Northern Territory, Australia, are described to illustrate the range of circumstances to which the simulation modelling can contribute. In all the case studies, the simulations were introduced by exploring vegetation and fire history data. Although many participants had previous exposure to the NAFI fire history data, it was rarely viewed in such a way that made explicit the relationship between historical fire regimes and future fire behaviour. In order to guide engagement with the simulation, several explorations were explicitly turned into a game. This was facilitated through the addition of a "game" within the simulation, a tool through which specific areas could be marked as requiring protection. If these defined "protection areas" are burnt, a large simulated explosion, indicating failure, is produced. More open-ended "play" allowed participants to think about fire behaviour and its implications for "good" fire management through self-driven exploration.

Indigenous communities in central Arnhem Land: Indigenous people were provided with simulations of fire on the land where the workshops occurred and to which the participants had traditional cultural responsibilities. The tailoring of the model to the local community and landscape meant that everyone had an intimate understanding of the context.

"Aspects of culture came to the fore as people found ways to exercise simulations according to their traditions. For example, a reluctance by senior people to burn country belonging to other clans, even in a simulated setting. This all contributed to supporting the workshop goals as it provided a vehicle for mix of new and existing knowledges" [73]. 
In order to facilitate more directed interaction with the model, a strategic fire management "game" was developed. Two participants were asked to mark locations in the model requiring protection from wildfire. There was careful deliberation over where to mark important (sacred) locations in the landscape which, in real life, require close management to protect them from fire.

The simulation sessions, during the fire management workshops, were generally run in the evening after a day of discussions and on-ground burning activities. The simulation outcomes were discussed in the context of the fresh information they received that day, but also in terms of their longstanding knowledge of their country. The simulations were seen as a valuable tool for supporting exchange between scientific and traditional fire stories, as well as for facilitating intergenerational knowledge exchange [73].

Indigenous Protected Area, Dhimurru: a fire workshop in an Indigenous managed area that included a large bauxite mine and free camping areas for adventure tourism allowed participants to explore the interaction between contemporary and traditional fire management. Participants included a mine representative, emergency services, Indigenous rangers, Indigenous Traditional Owners, and non-Indigenous ranger coordinators. Both Indigenous and non-Indigenous participants commented specifically on how the simulation help clarify and solidify their understanding of fire behaviour on their country. Layers representing fuel loads and fire history helped provide an understanding of current fire conditions and how fires were likely to behave, including the uncertainties around that behaviour. Participants commented on how the simulation helped them visualise fire behaviours leading them to a better, more informed position, and to work through the steps involved in rolling out a fire management program. One Indigenous ranger [74] described how:

"Fire is a complex thing affected by wind strength and direction and fuel and roads and things, but it was good because it pulled it all apart and helped us to understand what was happening, it showed things changing [through time], it reinforced what we had learnt on the ground when we had burnt before."

The visual nature of the simulation allowed participants with English as a second or third language to understand, engage in, and learn from the exercise to the same extent as those with a good command of English [73]. Cross-cultural engagement was also seen as an important outcome of the simulation. It was commented that the visual nature meant that participants with English as a second (or third) language, were able to understand, engage in and learn from the exercise to the same extent as those with a good command of English. Participants also emphasised the importance of local context and control over the simulation.

Indigenous women's ranger group: The Mimal simulation was provided to the Mimal Indigenous rangers, based in the remote community of Wemol, for their ongoing independent use. This was in contrast to the other Arnhem Land applications where the simulations were used to support individual workshops and facilitated by the senior author. The Indigenous women rangers became the primary users of the simulation to improve their own understanding of fire management and for presenting this knowledge to others. The ranger coordinator working with the Mimal group described how scientific explanations behind savanna burning methods do not always translate well in a crosscultural environment, whilst the simulations through the interactive gameplay helped provide context and a better understanding of their work. The ranger coordinator felt that the simulations helped develop deeper job satisfaction amongst the rangers. The rangers were able to see the results of their back-burning efforts played out in front of them in a way that appeared realistic and responded to the underlying landscape they knew.

The rangers subsequently used the simulation as a tool to teach the children at the local school about the right times of year to light fires. This information was fed back to their families in the form of take-home worksheets, with the intention of building more fire danger awareness amongst the children's families. [74]. 


\section{Discussion}

Sterman [11] describes how successful change in social systems requires "the active participation of a wide range of people in the modelling and policy design process, people who often lack technical training". Our fire simulation modelling aimed to change approaches to fire management at two stages through the development of the simulation model: as the model was being refined and by enabling model users to explore the consequences of different variables on fire in landscapes they knew well. As such, the simulations described in this paper aimed to capture the lived experience of fire behaviour in northern Australian savanna, using the best available data to describe the key landscape variables. The primary goal was to translate available fire-related data sets into a form that increased the understanding of fire and ecosystems dynamics in Northern Australian savannas.

In some places, participation was aided by existing cultural practice. For example, Indigenous people in Northern Australia often share complex ideas through stories and metaphor [75]. Thus, in the Indigenous workshops, uncertainty about fire behaviour was already implicit to the understanding of landscape processes. Debate, discussion and story exchange stimulated by the simulations were considered more important than their truth or accuracy. The complexity of fire behaviour was also explicitly acknowledged by one of the more experienced pastoral lease managers who described a fire on his land like a wild animal, "running" through grasslands, "hiding" for days in scrubland before "poking its head out and racing off again". The ability to represent the "wild" nature of wildfire is built into the interactive and stochastic nature of the models. Although the models described are relatively simple, the behaviour exhibited is often complex, explainable, but not always predictable. Being able to visualise unpredictable variability in fire behaviour through multiple model runs enabled a deeper appreciation of uncertainty and fits one of the learning goals, as defined by Voinov [39], of being "certain about uncertainty". Such probabilistic assessments of fire spread are commonly applied within Monte Carlo and deterministic simulations and are often used to assist fire management planning and outreach $[76,77]$. However, unique to this work is placing the operation and experimentation directly in the hands of land managers and to "see" this behaviour and learn for themselves.

Engagement with the simulations was also increased by goal-oriented gameplay, something that is often used as an educational tool with simulations, especially when teaching complexity [78]. Within the simulation, gamification could be expanded by scoring outcomes against key land management objectives. For example, the number of early Dry Season incendiaries dropped could be gamified as a measure of implementation costs versus the effectiveness of the breaks created in stopping late Dry Season fire, or in patch size in the fire mosaic. Additional measures could relate to carbon abatement or sensitive area protection scores. While careful consideration of the metrics used for scoring is needed to avoid oversimplifying the multi-faceted set of outcomes required from mitigation burns, competition to optimise solutions could help improve understanding of systems dynamics.

A secondary aim of the research was to show how key driving variables could influence fire behaviour. In most of the applications described, the ability to visualise the outcomes of a range of burning strategies dynamically was commented on as an important feature of the simulation. The ability to watch fires move and "see" fire behaviour evolving over previously static datasets significantly contributed to learning and engagement. Considering the landscape data in tandem with changing fire weather conditions also provided new insights amongst the Indigenous rangers into the dynamics of fire behaviour. Implementing more nuanced fire management aimed at decreasing the negative environmental impacts of large-scale fuel reduction burning is a concern for many land managers across Northern Australia [79-81].

The final aim was to support the communication of fire management objectives to a culturally diverse range of land managers. This was achieved during most of the workshops and public demonstrations, and was particularly significant in Arnhem Land, where 
many participants had low levels of formal institutional education and for whom English is a second or third language. In this context, the highly visual and interactive nature of simulations effectively enabled Indigenous knowledge to interact with scientific information, thereby supporting cross-cultural and intergenerational discussion. In many of the Arnhem Land demonstrations, after an initial introduction, interaction with the simulation was led by the Indigenous participants whose land was modelled. The simulations were therefore used to support local knowledge and help reinforce "good" fire management for younger community members.

This is an example of what can be achieved through innovative modelling solutions prioritising participation over prediction. Whilst this work is still a long way from what could be achieved to support Indigenous representation in cultural fire management, it does present a (complex system) approach that is enhanced by flexible and adaptive modelling. Further work could be done involving a deeper level of participation and collaboration with Indigenous land managers to incorporate key concepts of cultural burning practice-because this work focused on broad-scale savanna burning applications, it has not been able to accommodate some of the more refined cultural practices relating to small-scale fires.

The public demonstrations run by the government also effectively and quickly illustrated key concepts around the use of fire through fuel reductions burns undertaken to control fire. This was an important outcome as there is often confusion amongst people unfamiliar with savanna fire management as to the means by which fire can be used to manage fire. The case studies suggest positive learning and knowledge sharing outcomes from the use of the model. As is common in this form of stakeholder modelling applications, verification and validation of the model was user-based [82] in that it was seen to be credible and fit for purpose by the fire managers. In particular, a formal evaluation beyond the anecdotes provided by the case studies was not possible due to the remote, Indigenous and public forum context of the applications described. To the extent to which we accept "untraditional metrics of success and validation", as suggested by Voinov [39], for this type of participatory complex system modelling, some validation was provided by the fact that the model has been used by remote Indigenous rangers for knowledge transfer at a local school showing its utility for empowering local Indigenous voices to tell their own story about land and fire management. While the results were not subjected to a formal output validation, which constitutes a limitation in terms of its predictive power, though not its acceptability by the fire managers, output validation in the context of complex systems models can be problematic and may be less important than model transparency and use to gain a greater understanding of the underlying system [10].

\section{Conclusions}

Wildfire control is increasingly being viewed as a landscape management issue requiring a sophisticated understanding of complex, long term human-ecological interactions. There is, therefore, a case to be made for the broader use of fire simulation tools using a complex systems and participatory modelling approach that allow ecosystem management scenarios to be tested, evaluated and refined. It has long been argued that complex system thinking is imperative for addressing many interdisciplinary social, ecological and economic problems $[10,83-85]$. This paper suggests this is true for thinking of and learning about fire behaviour and is likely to have application in other environmental contexts. Though describing and understanding complex interactions can be difficult, visualisation and interaction was found to be an effective means to communicate complexity. In the words of Grimm [86]:

"If the whole process of modelling has succeeded, something will have happened in our head, namely that an understanding of relationships has emerged."

We developed the stochastic cellular automata fire simulation model to demonstrate both the complexity of fire in the savannas and how it can be managed. It produced fire behaviours that illustrated key fire management concepts with a relatively simple set 
of rules combined with a set of readily accessible fire data sets. The trial results, while anecdotal, demonstrate that the simulation can be applied across a wide range of social and cultural settings, stimulating conversation not just about fire, but also about the management of the country on which fire occurs.

Opportunities for equitable conversations about fire management are becoming increasingly important as concerns grown around how Indigenous voices are heard in natural and cultural resource management, particularly on their own lands $[13,15]$. Cognitively accessible and spatially explicit simulations of natural processes like fire of the type described here can help accommodate differences in Indigenous and non-Indigenous ways of thinking about environmental management and support two-way approaches to ecological research and managing country.

Supplementary Materials: The following are available online at https:/ / www.mdpi.com/article/10 $.3390 /$ fire4030046/s1.

Author Contributions: R.F. was responsible for the paper's conceptualisation, methodology and software. R.F., S.H. and S.G. contributed substantially to the original draft preparation, writingreview and editing. All authors have read and agreed to the published version of the manuscript.

Funding: This research received no external funding.

Institutional Review Board Statement: The study was conducted according to the guidelines of the Declaration of Helsinki and approved by the Ethics Committee of Charles Darwin University (CDU-HREC Ref: H17028) on 2017/11/10.

Informed Consent Statement: Informed consent was obtained from all subjects involved in the study.

Data Availability Statement: Example of the model described in this research area available at: https://github.com/rohanfisher/Fire_Sim.

Acknowledgments: The author would like to thank Peter Jacklyn, Peter Fisher and Jeremy Garnett for their assistance with drafts of this manuscript. In addition, we would like to acknowledge the following for their contribution to supporting this research: Steven Sutton, Dhimurru Aboriginal Corporation, Mimal Aboriginal Corporation, Lisa Roger and the communities of Buluhkaduru and Malanyangakk in Northern Australia.

Conflicts of Interest: The authors declare no conflict of interest.

\section{References}

1. Di Virgilio, G.; Evans, J.P.; Blake, S.A.P.; Armstrong, M.; Dowdy, A.J.; Sharples, J.; McRae, R. Climate Change Increases the Potential for Extreme Wildfires. Geophys. Res. Lett. 2019, 46, 8517-8526. [CrossRef]

2. Bowman, D.M.J.S.; Bradstock, R.A. California Is on Fire. From across the Pacific, Australians Watch on and California Is on Fire. From across the Pacific, Australians Watch on and Buckle up Buckle up. Available online: https://theconversation.com/ california-is-on-fire-from-across-the-pacific-australians-watch-on-and-buckle-up-145170 (accessed on 21 April 2021).

3. Ruane, S. Using a worldview lens to examine complex policy issues: A historical review of bushfire management in the South West of Australia. Local Environ. 2018, 23, 777-795. [CrossRef]

4. Marks-Block, T.; Tripp, W. Facilitating Prescribed Fire in Northern California through Indigenous Governance and Interagency Partnerships. Fire 2021, 4, 37. [CrossRef]

5. Russell-Smith, J.; Cook, G.D.; Cooke, P.M.; Edwards, A.C.; Lendrum, M.; Meyer, C.P.; Whitehead, P.J. Managing fire regimes in north Australian savannas: Applying Aboriginal approaches to contemporary global problems. Front. Ecol. Environ. 2013, 11. [CrossRef]

6. Pyne, S.J. The Pyrocene: How We Created an Age of Fire, and What Happens Next; University of California Press: Berkeley, CA, USA, 2021.

7. Russell-Smith, J. Fire management business in Australia's tropical savannas: Lighting the way for a new ecosystem services model for the north? Ecol. Manag. Restor. 2016, 17, 4-7. [CrossRef]

8. Ansell, J.; Evans, J.; Rangers, A.; Rangers, A.S.; Rangers, D.; Rangers, J.; Rangers, M.; Rangers, N.N.; Rangers, W.; Rangers, Y.; et al. Contemporary Aboriginal savanna burning projects in Arnhem Land: A regional description and analysis of the fire management aspirations of Traditional Owners. Int. J. Wildland Fire 2020, 29, 371-385. [CrossRef]

9. Petty, A.M.; deKoninck, V.; Orlove, B. Cleaning, Protecting, or Abating? Making Indigenous Fire Management "Work" in Northern Australia. J. Ethnobiol. 2015, 35, 140-162. [CrossRef] 
10. Green, D.G.; Sadedin, S. Interactions matter-Complexity in landscapes and ecosystems. Ecol. Complex. 2005, 2, 117-130. [CrossRef]

11. Sterman, J. Learning in and about complex systems. Syst. Dyn. Rev. 1994, 10, 291-330. [CrossRef]

12. Burton, R.M.; Obel, B. The Validity of Computational Models in Organization Science: From Model Realism to Purpose of the Model; Springer: Berlin/Heidelberg, Germany, 1995; Volume 1, pp. 57-71. [CrossRef]

13. Ens, E.J.; Pert, P.; Clarke, P.A.; Budden, M.; Clubb, L.; Doran, B.; Douras, C.; Gaikwad, J.; Gott, B.; Leonard, S.; et al. Indigenous biocultural knowledge in ecosystem science and management: Review and insight from Australia. Biol. Conserv. 2015, 181, 133-149. [CrossRef]

14. Ens, E.J.; Finlayson, M.; Preuss, K.; Jackson, S.; Holcombe, S. Australian approaches for managing 'country' using Indigenous and non-Indigenous knowledge. Ecol. Manag. Restor. 2012, 13, 100-107. [CrossRef]

15. Bohensky, E.; Butler, J.; Davies, J. Integrating Indigenous Ecological Knowledge and Science in Natural Resource Management: Perspectives from Australia. Ecol. Soc. 2013, 18. [CrossRef]

16. Davies, J.; Hill, R.; Walsh, F.J.; Sandford, M.; Smyth, D.; Holmes, M.C.; Davies, J.; Hill, R.; Walsh, F.J.; Sandford, M.; et al. Innovation in Management Plans for Community Conserved Areas: Experiences from Australian Indigenous Protected Areas. Ecol. Soc. 2013, 18. [CrossRef]

17. Bohensky, E.L.; Maru, Y. Indigenous knowledge, science, and resilience: What have we learned from a decade of international literature on "integration"? Ecol. Soc. 2011, 16. [CrossRef]

18. Farina, A. Complexity theory and landscape ontogenesis: An epistemological approach. Int. J. Risk Assess. Manag. 2005, 5, 159-166. [CrossRef]

19. $\mathrm{Wu}$, J.; David, J.L. A spatially explicit hierarchical approach to modeling complex ecological systems: Theory and applications. Ecol. Model. 2002, 153, 7-26. [CrossRef]

20. An, L. Modeling human decisions in coupled human and natural systems: Review of agent-based models. Ecol. Model. 2012, 229, 25-36. [CrossRef]

21. Santoni, P.A.; Filippi, J.B.; Balbi, J.H.; Bosseur, F. Wildland fire behaviour case studies and fuel models for landscape-scale fire modeling. J. Combust. 2011, 2011. [CrossRef]

22. Alexander, M.E.; Cruz, M.G. Limitations on the accuracy of model predictions of wildland fire behaviour: A state-of-theknowledge overview. For. Chron. 2013, 89, 370-381. [CrossRef]

23. Mccormick, R.J.; Brandner, T.A.; Allen, T.F.H.; Drive, L. Toward a Theory of Meso-Scale Wildfire Modeling-A Complex Systems Approach Using Artificial Neural Networks; The University of Wisconsin-Madison: Madison, WI, USA, 1997.

24. Rothermel, R.C.; Rinehart, G.C. Field Procedures for Verification and Adjustment of Fire Behavior Predicitions; U.S. Department of Agriculture, Forest Service, Intermountain Forest and Range Experiment Station: Ogden, UT, USA, 1983.

25. Anderson, D.H.; Catchpole, E.A.; De Mestre, N.J.; Parkes, T. Modelling the spread of grass fires. J. Aust. Math. Soc. Ser. B. Appl. Math. 1982, 23, 451-466. [CrossRef]

26. Cheney, N.; Gould, J. Fire Growth in Grassland Fuels. Int. J. Wildland Fire 1995, 5, 237. [CrossRef]

27. Fernandes, P.A.M.; Loureiro, C.A.; Botelho, H.S. Fire behaviour and severity in a maritime pine stand under differing fuel conditions. Ann. For. Sci. 2004, 61, 537-544. [CrossRef]

28. Trigo, R.M.; Pereira, J.M.C.; Fernandes, P.M.; Ervilha, A.R.; Sá, A.C.L.; Pinto, R.M.S.; Benali, A. Deciphering the impact of uncertainty on the accuracy of large wildfire spread simulations. Sci. Total Environ. 2016, 569-570, 73-85. [CrossRef]

29. Dawson, R.; Peppe, R.; Wang, M. An agent-based model for risk-based flood incident management. Nat. Hazards 2011, 59, 167-189. [CrossRef]

30. Gaillard, J.C.; Monteil, C.; Perrillat-Collomb, A.; Chaudhary, S.; Chaudhary, M.; Chaudhary, O.; Giazzi, F.; Cadag, J.R.D.; Skagerlund, K.; Kirsh, D. Participatory 3-dimension mapping: A tool for encouraging multi-caste collaboration to climate change adaptation and disaster risk reduction. Appl. Geogr. 2013, 45, 158-166. [CrossRef]

31. Taillandier, F.; Adam, C. Games Ready to Use: A Serious Game for Teaching Natural Risk Management. Simul. Gaming 2018, 49, 441-470. [CrossRef]

32. Heckbert, S.; Baynes, T.; Reeson, A. Agent-based modeling in ecological economics. Ann. N. Y. Acad. Sci. 2010, 1185, 39-53. [CrossRef]

33. Millington, J.D.A.; Demeritt, D.; Romero-Calcerrada, R. Participatory evaluation of agent-based land-use models. J. Land Use Sci. 2011, 6, 195-210. [CrossRef]

34. Ruankaew, N.; Le Page, C.; Dumrongrojwattana, P.; Barnaud, C.; Gajaseni, N.; van Paassen, A.; Trébuil, G. Companion modelling for integrated renewable resource management: A new collaborative approach to create common values for sustainable development. Int. J. Sustain. Dev. World Ecol. 2010, 17, 15-23. [CrossRef]

35. Le Page, C.; Bazile, D.; Becu, N. Agent-Based Modelling and Simulation Applied to Environmental Management. In Simulating Social Complexity; Springer: Berlin/Heidelberg, Germany, 2013.

36. d'Aquino, P.; Bah, A. A participatory modeling process to capture indigenous ways of adaptability to uncertainty: Outputs from an experiment in west African drylands. Ecol. Soc. 2013, 18. [CrossRef]

37. Barreteau, O.; Le Page, C.; Perez, P. Contribution of simulation and gaming to natural resource management issues: An introduction. Simul. Gaming 2007, 38, 185-194. [CrossRef] 
38. Barreteau, O.; Bots, P.W.G.; Daniell, K.A.; Etienne, M.; Perez, P.; Barnaud, C.; Bazile, D.; Becu, N.; Castella, J.-C.; Dare, W.; et al. Participatory approaches and simulation of social complexity. In A Handbook on Simulating Social Complexity; Springer: Berlin/Heidelberg, Germany, 2013; ISBN 978-3-540-93812-5.

39. Voinov, A.; Bousquet, F. Environmental Modelling \& Software Modelling with stakeholders. Environ. Model. Softw. 2010, 25, 1268-1281.

40. Robinson, C.J.; Wallington, T.J. Boundary work: Engaging knowledge systems in co-management of feral animals on indigenous lands. Ecol. Soc. 2012, 17. [CrossRef]

41. Hare, M. Forms of participatory modelling and its potential for widespread adoption in the water sector. Environ. Policy Gov. 2011, 21, 386-402. [CrossRef]

42. Dwyer, E.; Pinnock, S.; Gregoire, J.-M.; Pereira, J.M.C. Global spatial and temporal distribution of vegetation fire as determined from satellite observations. Int. J. Remote Sens. 2000, 21, 1289-1302. [CrossRef]

43. Russell-Smith, J.; Yates, C.P.; Edwards, A.C.; Whitehead, P.J.; Murphy, B.P.; Lawes, M.J. Deriving Multiple Benefits from Carbon Market-Based Savanna Fire Management: An Australian Example. PLoS ONE 2015, 10, e0143426. [CrossRef] [PubMed]

44. Price, O.; Russell-Smith, J.; Watt, F. The influence of prescribed fire on the extent of wildfire in savanna landscapes of western Arnhem Land, Australia. Int. J. Wildland Fire 2012, 21, 297-305. [CrossRef]

45. Heckbert, S.; Russell-Smith, J.; Reeson, A.; Davies, J.; James, G.; Meyer, C. Spatially explicit benefit-cost analysis of fire management for greenhouse gas abatement. Austral Ecol. 2012, 37, 724-732. [CrossRef]

46. Franklin, D.C.; Whitehead, P.J.; Pardon, G.; Matthews, J.; McMahon, P.; McIntyre, D. Geographic patterns and correlates of the decline of granivorous birds in northern Australia. Wildland Res. 2005, 32, 399-408. [CrossRef]

47. Woinarski, J.C.Z.; Legge, S.; Fitzsimons, J.A.; Traill, B.J.; Burbidge, A.A.; Fisher, A.; Firth, R.S.C.; Gordon, I.J.; Griffiths, A.D.; Johnson, C.N.; et al. The disappearing mammal fauna of northern Australia: Context, cause, and response. Conserv. Lett. 2011, 4, 192-201. [CrossRef]

48. Edwards, A.; Russell-Smith, J.; Meyer, M. Contemporary fire regime risks to key ecological assets and processes in north Australian savannas. Int. J. Wildland Fire 2015, 24, 857-870. [CrossRef]

49. Williams, R.J.; Gill, A.M.; Moore, P.H.R. Seasonal Changes in Fire Behaviour in a Tropical Savanna in Northern Australia. Int. J. Wildland Fire 1998, 8, 227-239. [CrossRef]

50. Fitzsimons, J.; Russell-Smith, J.; James, G.; Vigilante, T.; Lipsett-Moore, G.; Morrison, J.; Looker, M. Insights into the biodiversity and social benchmarking components of the Northern Australian fire management and carbon abatement programmes. Ecol. Manag. Restor. 2012, 13, 51-57. [CrossRef]

51. Price, O.; Edwards, A.; Connors, G.; Woinarski, J.; Ryan, G.; Turner, A.; Russell-Smith, J. Fire heterogeneity in Kakadu National Park, 1980-2000. Wildland Res. 2005, 32, 425-433. [CrossRef]

52. Russell-Smith, J.; Edwards, A.C.; Cook, G.D.; Schatz, J.; Brocklehurst, P. Estimating greenhouse gas emissions from savanna burning in northern Australia. For. Ecol. Manag. 2006, 234, S152. [CrossRef]

53. Meyer, C.P.; Cook, G.D.; Reisen, F.; Smith, T.E.L.; Tattaris, M.; Russell-Smith, J.; Maier, S.W.; Yates, C.P.; Wooster, M.J. Direct measurements of the seasonality of emission factors from savanna fires in northern Australia. J. Geophys. Res. Atmos. 2012, 117. [CrossRef]

54. Russell-Smith, J.; Thornton, R. Perspectives on prescribed burning. Front. Ecol. Environ. 2013, 11, e3-e71.

55. Edwards, A.; Russell-Smith, J.; Price, O. Fine-scale patchiness of different fire intensities in sandstone heath vegetation in northern Australia. Int. J. Wildland Fire 2003, 12, 227. [CrossRef]

56. Russell-Smith, J.; Edwards, A.C. Seasonality and fire severity in savanna landscapes of monsoonal northern Australia. Int. J. Wildland Fire 2006, 15, 541-550. [CrossRef]

57. Dyer, R.; Russell-Smith, J.; Grice, T.; McGuffog, C.; Yibarbuk, D. Using fire to manage savanna. In Savanna Burning: Understanding and Using Fire in Northern Australia; Dyer, R., Jacklyn, P., Partridge, I., Russell-Smith, J., Williams, D., Eds.; The Tropical Savannas CRC: Darwin, Australia, 2001. Available online: https://publications.csiro.au/rpr/pub?list=BRO\&pid=procite: 3c331fc9-9c82-43f2-8e1f-db8361ad754c (accessed on 1 June 2021).

58. Jacklyn, P.; Ansell, S.; Crosbie, A.; Holmes, J.; Joseph, A.; Legge, S.; Lewis, B.; Pickworth, A.; Vigilante, T.; Weigl, J. The operational role of satellite-based fire data in savanna burning methodologies. In Carbon Accounting and Savanna Fire Management; CSIRO Publishing: Clayton, Australia, 2015; pp. 97-113.

59. NAFI. Available online: Firenorth.org.au (accessed on 18 April 2020).

60. Wilensky, U.; Rand, W. An Introduction to Agent-Based Modeling:Modeling Natural, Social, and Engineered Complex Systems with NetLogo; MIT Press: Cambridge, MA, USA, 2015; ISBN 9780262731898.

61. Achtemeier, G.L. Field validation of a free-agent cellular automata model of fire spread with fire-Atmosphere coupling. Int. J. Wildland Fire 2013, 22, 148. [CrossRef]

62. Berjak, S.G.; Hearne, J.W. An improved cellular automaton model for simulating fire in a spatially heterogeneous Savanna system. Ecol. Model. 2002, 148, 133-151. [CrossRef]

63. Alexandridis, A.; Russo, L.; Vakalis, D.; Bafas, G. Wildland fire spread modelling using cellular automata: Evolution in large-scale spatially heterogeneous environments under fire suppression tactics. Int. J. Wildland Fire 2011, 20, 633-647. [CrossRef]

64. Garnett, S.T.; Williamson, G. Spatial and temporal variation in precipitation at the start of the rainy season in tropical Australia. Rangel. J. 2010, 32, 215-226. [CrossRef] 
65. Storey, M.A.; Price, O.F.; Sharples, J.J.; Bradstock, R.A. Drivers of long-distance spotting during wildfires in south-eastern Australia. Int. J. Wildland Fire 2020, 29, 459-472. [CrossRef]

66. Stull, R.B. An Introduction to Boundary Layer Meteorology; Springer Science \& Business Media: Berlin, Germany, 1988. [CrossRef]

67. Yates, C.P.; Russell-Smith, J.; Murphy, B.P.; Desailly, M.; Evans, J.; Legge, S.; Lewis, F.; Lynch, D.; Edwards, A.C. Fuel accumulation, consumption and fire patchiness in the lower rainfall savanna region. In Carbon Accounting and Savanna Fire Management; CSIRO Publishing: Clayton, Australia, 2015; pp. 115-132.

68. ANZLIC ELVIS-Elevation and Depth-Foundation Spatial Data. Available online: https://elevation.fsdf.org.au/ (accessed on 19 August 2020).

69. Meteorology, T.B. Available online: http://www.bom.gov.au/water/geofabric/download.shtml (accessed on 19 August 2020).

70. Noble, I.; Gill, A.; Bary, G. McArthur's fire-danger meters expressed as equations. Aust. J. Ecol. 1980, 5, 201-203. [CrossRef]

71. Cheney, P.; Sullivan, A. Grassfires: Fuel, Weather and Fire Behaviour; CSIRO Publishing: Clayton, Australia, 2008.

72. Griffin, G.F.; Allan, G.E. Fire behaviour. In Anticipating the Inevitable: A Patch Burn Strategy for Fire Management at Uluru (Ayers Rock-Mt Olga) National Park; Saxon, E., Ed.; CSIRO: Australia, Melbourne, 1984.

73. Sutton, S.; University of Alberta, Edmonton, AB, Canada. Personal communication, 2017.

74. Salt, J.; Cranfield University, Cranfield, UK. Personal communication, 2018.

75. Sharifian, F. Conceptual Metaphor in Intercultural Communication between Speakers of Aboriginal English and Australian English. In Metaphor and Intercultural Communication; Bloomsbury Academic: London, UK, 2014.

76. Finney, M.A.; Grenfell, I.C.; McHugh, C.W.; Seli, R.C.; Trethewey, D.; Stratton, R.D.; Brittain, S. A Method for Ensemble Wildland Fire Simulation. Environ. Model. Assess. 2011, 16, 153-167. [CrossRef]

77. Parisien, M.A.; Dawe, D.A.; Miller, C.; Stockdale, C.A.; Armitage, O.B. Applications of simulation-based burn probability modelling: A review. Int. J. Wildland Fire 2019, 28, 913-926. [CrossRef]

78. Rumeser, D.; Emsley, M. A systematic review of project management serious games: Identifying gaps, trends, and directions for future research. J. Mod. Proj. Manag. 2018, 6, 60-68. [CrossRef]

79. Evans, J.; Russell-Smith, J. Delivering effective savanna fire management for defined biodiversity conservation outcomes: An Arnhem Land case study. Int. J. Wildland Fire 2019, 29, 386-400. [CrossRef]

80. Corey, B.; Andersen, A.N.; Legge, S.; Woinarski, J.C.Z.; Radford, I.J.; Perry, J.J. Better biodiversity accounting is needed to prevent bioperversity and maximize co-benefits from savanna burning. Conserv. Lett. 2019, 13. [CrossRef]

81. Russell-Smith, J.; Evans, J.; Edwards, A.C.; Simms, A. Assessing ecological performance thresholds in fire-prone Kakadu National Park, Northern Australia. Ecosphere 2017, 8, e01856. [CrossRef]

82. Greiner, R.; Puig, J.; Huchery, C.; Collier, N.; Garnett, S.T. Scenario modelling to support industry strategic planning and decision making. Environ. Model. Softw. 2014, 55, 120-131. [CrossRef]

83. Wu, J.; Marceau, D. Modeling complex ecological systems: An introduction. Ecol. Model. 2002, 153, 1-6. [CrossRef]

84. Zellner, M.L. Embracing Complexity and Uncertainty: The Potential of Agent-Based Modeling for Environmental Planning and Policy. Plan. Theory Pract. 2008, 9, 437-457. [CrossRef]

85. Beratan, K.K. A Cognition-based View of Decision Processes in Complex Social-Ecological Systems. Ecol. Soc. 2007, 12, 27. [CrossRef]

86. Grimm, V. Ten years of individual-based modelling in ecology: What have we learned and what could we learn in the future? Ecol. Model. 1999, 115, 129-148. [CrossRef] 